\title{
Laboratory Study on Precipitation of Barium Sulphate in Malaysia Sandstone Cores
}

\author{
Amer Badr Bin Merdhah* and Abu Azam Mohd Yassin
}

Faculty of Chemical and Natural Resources Engineering, Universiti Teknologi Malaysia. 81310 Skudai, Johor, Malaysia

\begin{abstract}
Scale formation is one of the most serious oil field problems that inflict water injection systems primarily when two incompatible waters are involved. Two waters are incompatible if they interact chemically and precipitate minerals when mixed. Due to the lack of reaction kinetics data, the rate of barium sulphate deposition in porous rock was measured through flooding sandstone core samples of uniform properties with supersaturated brine. The brine was formulated at the core inlet by mixing of injected sea water and formation water that contained high concentration of barium ion at various temperatures $\left(50-80^{\circ} \mathrm{C}\right)$ and differential pressures $(100-200 \mathrm{psig})$. The rate of $\mathrm{BaSO}_{4}$ scale formation was estimated by monitoring the core effluent's barium ion concentration. The solubility of barium sulphate scale formed and how its solubility was affected by changes in salinity and temperatures $\left(40-90^{\circ} \mathrm{C}\right)$ were also studied. Scanning Electron Microscopy analysis was also used to examine the nature of scale deposition throughout the core. The results indicated increased rate of $\mathrm{BaSO}_{4}$ precipitation at higher temperatures and greater brine super-saturation. The results were utilized to build a general reaction rate equation to predict $\mathrm{BaSO}_{4}$ deposition in sandstone cores for a given temperature, brine super-saturation and differential pressures.
\end{abstract}

Keywords: Scale deposition, scale solubility, concentration of barium ion, temperature and pressure effects.

\section{INTRODUCTION}

The injection of seawater into oilfield reservoirs to maintain reservoir pressure and improve secondary recovery is a well-established and mature operation. Moreover, the degree of risk posed by deposition of mineral scales to the injection and production wells during such operations has been much studied. Scale deposition is one of the most serious oil field problems that inflict water injection systems primarily when two incompatible waters are involved.

Due to the limited availability of reaction kinetics data in the literature, especially for barium sulfate precipitation within porous media, this study was conducted to measure and model the rate of this reaction. Since this was intended to be the first in a series of progressively elaborate studies, investigation was focused on the brine's concentration and flow conditions rather than the porous medium.

\section{OILFIELD SCALE TYPES}

The most common oil field scales are listed in Table 1, along with the primary variables that affect their solubility [1]. These scales are sulfates such as calcium sulfate (anhydrite, gypsum), barium sulfate (barite), Strontium sulfate (celestite) and calcium carbonate. Other less common scales have also been reported such as iron oxides, iron sulfides and iron carbonate. Lead and zinc sulfide scale has recently become a concern in a number of North Sea oil and gas fields [2].

*Address correspondence to this author at the Faculty of Chemical and Natural Resources Engineering, Universiti Teknologi Malaysia. 81310 Skudai, Johor, Malaysia; E-mail: amer0227@yahoo.com

\section{SCALE DEPOSITION MECHANISMS}

Scale deposition in surface and subsurface oil and gas production equipment has been recognized. Scale deposition is one of the most important and serious problems that inflict oil field water injection systems. Scale limits and sometimes blocks oil and gas production by plugging the oilproducing formation matrix or fractures and perforated intervals. It can also plug production lines and equipment and impair fluid flow. Scale also deposited in down-hole pumps, tubing, casing flow-lines, heater treaters, tanks and other production equipment and facilities. The consequence could be production-equipment failure, emergency shutdown, increased maintenance cost, and overall decrease in production efficiency. In case of water injection systems, scale could plug the pores of the formation and results in injectivity decline with time [3-8]. Scale also can deposit when two incompatible waters are mixed and supersaturation is reached [3,9-13].

\section{SOURCE OF OIL FIELD SCALE}

The chief source of oil field scale is mixing of incompatible waters. Two waters are called incompatible if they interact chemically and precipitate minerals when mixed. A typical example of incompatible waters is sea water with high concentration of $\mathrm{SO}_{4}^{-2}$ and low concentrations of $\mathrm{Ca}^{+2}$, $\mathrm{Ba}^{+2} / \mathrm{Sr}^{+2}$, and formation waters with very low concentrations of $\mathrm{SO}_{4}{ }^{-2}$ but high concentrations of $\mathrm{Ca}^{+2}, \mathrm{Ba}^{+2}$ and $\mathrm{Sr}^{+2}$. Mixing of these waters, therefore, causes precipitation of $\mathrm{CaSO}_{4}$, $\mathrm{BaSO}_{4}$, and/or $\mathrm{SrSO}_{4}$. Field produced water (disposal water) can also be incompatible with seawater. In cases where disposal water is mixed with seawater for re-injection, scale deposition is possible $[4,6,7,14,15]$. 
Table 1. Most Common Oilfield Scales

\begin{tabular}{|l|c|c|}
\hline \multicolumn{1}{|c|}{ Name } & Chemical Formula & Primary Variables \\
\hline \hline Calcium Carbonate & $\mathrm{CaCO}_{3}$ & Partial pressure of $\mathrm{CO}_{2}$, temperature, total dissolved salts, $\mathrm{pH}$ \\
\hline Calcium Sulfate: & & Temperature, total dissolved salts, pressure \\
Gypsum & $\mathrm{CaSO}_{4} \cdot 2 \mathrm{H}_{2} \mathrm{O}$ & \\
Hemihydrate & $\mathrm{CaSO}_{4} \cdot \mathrm{H}_{2} \mathrm{O}$ & \\
Anhydrite & $\mathrm{CaSO}_{4}$ & Temperature, pressure \\
\hline Barium Sulfate & $\mathrm{BaSO}_{4}$ & Temperature, pressure, total dissolved salts \\
\hline Strontium Sulfate & $\mathrm{SrSO}_{4}$ & Corrosion, dissolved gases, $\mathrm{pH}$ \\
\hline Iron Compounds: & $\mathrm{FeCO}$ & \\
Ferrous Carbonate & $\mathrm{FeS}$ & $\mathrm{Fe}(\mathrm{OH})_{2}$ \\
Ferrous Sulfide & $\mathrm{Fe}(\mathrm{OH})_{3}$ & \\
Ferrous Hydroxide & & \\
Ferrous Hydroxide & & \\
\hline
\end{tabular}

\section{SCALE FORMATION ALONG THE INJECTION- WATER PATH IN WATER-FLOOD OPERATIONS}

At the injection wellhead, injection water temperature is usually much lower than reservoir temperature. When it travels down the injection well-string, the water cools the surrounding formations, and its temperature and pressure increase. If the water is saturated at surface conditions with salts whose solubility decreases with increasing temperatures (e.g. anhydrite), scale may form along the well-string.

Scale precipitation from the injection water may happen behind the mixing zone as a consequence of temperature and pressure changes. This is particularly true of waters containing salts whose solubility decreases with increasing temperature and decreasing pressure. Forward of the mixing zone only reservoir brine (with oil) is present in the rock pores. Behind the mixing zone, only injected water in equilibrium at local temperature and pressure (with residual oil) exists. In the mixing zone, precipitation of insoluble salts may occur due to the interaction, at local temperature and pressure, of chemical species contained in the injection water with chemical species present in the reservoir brine.

Nevertheless, at a different pressure, the remaining clear water moves ahead mix again with reservoir brine and scale precipitation may again take place. This cycle is repeated until the remaining clear water reaches a production well. Pressure and temperature decrease along the flow string up to the surface in the production well, and further changes in thermodynamic conditions occur in the surface equipment. This may again result in scale formation. Normally, these scales do the most damage in the well-bore when there are major falls in pressure but hardly any temperature changes [16].

There are three principal mechanisms by which scales form in both offshore and onshore oil field system $[17,18]$ :

a) Decrease in pressure and/or increase in temperature of a brine, goes to a reduction in the solubility of the salt (most commonly these lead to precipitation of carbonate scales, such as $\mathrm{CaCO}_{3}$ ).

$$
\mathrm{Ca}\left(\mathrm{HCO}_{3}\right)_{2} \Leftrightarrow \mathrm{CaCO}_{3}+\mathrm{CO}_{2}+\mathrm{H}_{2} \mathrm{O}
$$

b) Mixing of two incompatible brines (most commonly formation water rich in cations such as barium, calcium and/or strontium, mixing with sulfate rich seawater, goes to the precipitation of sulfate scales, such as $\mathrm{BaSO}_{4}$ ).

$$
\begin{aligned}
& \mathrm{Ba}^{2+}\left(\text { or } \mathrm{Sr}^{2+} \text { or } \mathrm{Ca}^{2+}\right)+\mathrm{SO}_{4}^{2-} \Leftrightarrow \\
& \mathrm{BaSO}_{4}\left(\text { or } \mathrm{SrSO}_{4} \text { or } \mathrm{CaSO}_{4}\right)
\end{aligned}
$$

c) Other fluid incompatibilities include sulfide scale where hydrogen sulfide gas mixes with iron, zinc or lead rich formation waters:

$$
\mathrm{Zn}^{2+}+\mathrm{H}_{2} \mathrm{~S} \Leftrightarrow \mathrm{ZnS}+2 \mathrm{H}^{2+}
$$

brine evaporation, resulting in salt concentration increasing above the solubility limit and goes to salt precipitation (as may occur in HP/HT gas wells where a dry gas stream may mix with a low rate brine stream resulting in dehydration and most commonly the precipitation of $\mathrm{NaCl}$ ).

\section{THE SCALING PROBLEM IN OIL FIELDS}

A scale problem will occur, if at a high water cut part of the water is present as free water. The rate of scale deposition will then be approximately proportional to the rate of free water production. Depending upon where the formation water becomes supersaturated, scale may be deposited in the flow line only, in both flow line and tubing, and in some cases even in the perforations and in the formation near the wellbore.

Scale formation is a major problem in the oil industry. They may occur down-hole or in surface facilities. The formations of these scales plug production lines and equipment and impair fluid flow. Their consequence could be production-equipment failure, emergency shutdown, increased maintenance cost, and an overall decrease in production efficiency. The failure of production equipment and instruments could result in safety hazards [19].

Many case histories of oil well scaling by calcium carbonate, calcium sulfate, strontium sulfate and barium sulfate have been reported [20-23]. Problems in connection to oil 
well scaling in the Russia where scale has seriously plugged wells and are similar to cases in North Sea fields have been reported [20]. Oilfields scale problems have occurred because of water flooding in Saudi oil fields, Algeria, Indonesia in south Sumatra oilfields, and Egypt in el-Morgan oilfield where calcium and strontium sulfate scales have been found in surface and subsurface production equipment [24].

\section{SOLUBILITY OF SCALES}

"Solubility" is defined as the limiting amount of solute that can dissolve in a solvent under a given set of physical conditions. The chemical species of interest to us are present in aqueous solutions as ions. Certain combinations of these ions lead to compounds, which have low solubility. Once this capacity or solubility is exceeded the compounds precipitate from solution as solids. Therefore, precipitation of solid materials, which may form scale, will occur if:

(i) The water contains ions, which are capable of forming compounds of limited solubility.

(ii) There is a change in the physical conditions or water composition, lowering the solubility.

Factors that affect scale precipitation, deposition and crystal growth can be summarized as: super-saturation, temperature, pressure, ionic strength, evaporation, contact time and $\mathrm{pH}$. Effective scale control should be one of the primary objectives of any efficient water injection and normal production operation in oil and gas fields.

Barium sulfate scale (barite) in oil fields can be precipitated easily on the basis of already available information relating to thermodynamic condition and the kinetics of precipitation $[20,25]$. Barium sulfate solubility increased with temperature increase, with increase ionic strength of brine, and with pressure. Barium sulfate precipitation was affected most strongly by temperature [1].

\section{REACTION KINETICS}

For a homogenous simple chemical reaction,

\section{$\mathrm{A}+\mathrm{B} \longrightarrow \mathrm{C}$}

The reaction rate $(\mathrm{R})$ is defined as the change in the amount of a reaction per unit time per unit volume of reaction mixture. If the amount is measured in moles, then $\mathrm{R}$ becomes

$R=\frac{-d C_{A}}{d t}=\frac{-d C_{B}}{d t}=\frac{-d C_{C}}{d t}$

where: $C_{A}, C_{B}$, and $C_{C}$ are the molar concentration (m) of species $\mathrm{A}, \mathrm{B}$ and $\mathrm{C}$, respectively.

For a first order reaction, the rate of the reaction is proportional to the product of the concentrations of the reactants:

$\mathrm{R}=\mathrm{K} \mathrm{C}_{\mathrm{A}} \mathrm{C}_{\mathrm{B}}$

where: $\mathrm{K}$ is the proportionality constant, also known as the constant reaction rate. Equation (4) is called the rate law equation for the reaction.

The rate constant of most reactions is related to the absolute temperature by the Arrhenius equation:
$K=A e^{\left(\frac{-E_{A}}{R T}\right)}$

where,

A: frequency factor

$E_{\mathrm{A}}$ : reaction activation energy, $\mathrm{J} / \mathrm{mole}$

$\mathrm{R}$ : Universal gas constant $=8.314 \mathrm{~J} \mathrm{~mole}^{-1} \mathrm{~K}^{-1}$

T: absolute temperature, ${ }^{\circ} \mathrm{K}$.

If the Arrhenius equation applies, a plot of $\ln \mathrm{K}$ versus $1 / T$ should given a straight line of slope (-E/R) and intercept $\ln \mathrm{A}$. The frequency factor could depend on temperature, pressure and ionic strength of the solution.

For $\mathrm{BaSO}_{4}$ Precipitation Reaction:

$\mathrm{Ba}^{++}+\mathrm{SO}_{4}^{--} \longrightarrow \mathrm{BaSO}_{4}$

Many rate laws have been proposed in the literature [26, 27]. But we used one of the rate laws was:

$K=R K_{s p} / \mathrm{C}_{\mathrm{Ba}} \mathrm{C}_{\mathrm{SO}_{4}}$

where:

$\mathrm{K}$ : kinetic rate constant $\left(\mathrm{m} . \mathrm{min}^{-1}\right)$

$\mathrm{R}$ : rate of the $\mathrm{BaSO}_{4}$ precipitation reaction (m. $\mathrm{min}^{-1}$ )

$\mathrm{C}_{\mathrm{Ba}}, \mathrm{C}_{\mathrm{SO} 4 \text { : average steady-state concentrations of the ions }}$ across the core $(\mathrm{m})$

$\mathrm{K}_{\text {sp: }}$ solubility product of $\mathrm{BaSO}_{4}$ in solution under the conditions of the reaction.

\section{MATERIALS AND METHODS}

\section{Core Material}

In all flooding experiments, sandstone cores from Malaysia with 3inch length and of diameter 1 inch with average porosity of $32 \%$ and of absolute permeability varied from $12.30-13.84 \mathrm{md}$. No oil was present in the cores. All the cores were cleaned using methanol in Soxhlet extractor and dried in a Memmert Universal Oven at $100{ }^{\circ} \mathrm{C}$ for overnight before use.

\section{Brines}

The ionic compositions of synthetic formation water and water injection (Angsi and Barton seawaters) are given in Table 2. Note the formation water has barium ion, and the sea water contains sulphate ion. It is clear that the mixing of these waters can lead to barium sulphates precipitation.

Seven salts used for the preparation of synthetic formation water and water injections, the description of these salts are as follow:

(1) Sodium Chloride grade (AR) $\mathrm{NaCl}$ (M.Wt. $=58.44$ $\mathrm{g} / \mathrm{mol}, 99.8 \%$ purity) supplied by QReCTM.

(2) Potassium Sulphate $\mathrm{K}_{2} \mathrm{SO}_{4}$ (M.Wt. $=174.25 \mathrm{~g} / \mathrm{mol}$, 99\% purity) supplied by BHD chemicals Ltd Pool England.

Magnesium Chloride $\mathrm{MgCl}_{2} \cdot 6 \mathrm{H}_{2} \mathrm{O}$ (M.Wt. $=203.30$ $\mathrm{g} / \mathrm{mol}, 98 \%$ purity) supplied by R\&M Chemicals. 
(4) Calcium Chloride (dihydrate) grade (AR) $\mathrm{CaCl}_{2} .2 \mathrm{H}_{2} \mathrm{O}$ (M.Wt. $=147.02 \mathrm{~g} / \mathrm{mol}, 78 \%$ purity) supplied by QReCTM.

(5) Sodium Bicarbonate $\mathrm{NaHCO}_{3}$ (M.Wt. $=84.01 \mathrm{~g} / \mathrm{mol}$, $99.5 \%$ purity) supplied by GCE Laboratory Chemicals.

(6) Strontium Chloride (6-hydrate) $\mathrm{SrCl}_{2} \cdot 6 \mathrm{H}_{2} \mathrm{O}$ (M.Wt. = $266.62 \mathrm{~g} / \mathrm{mol}, 99 \%$ purity) supplied by GCE Laboratory Chemicals.

(7) Barium Chloride (dihydrate) grade (AR) $\mathrm{BaCl}_{2} \cdot 2 \mathrm{H}_{2} \mathrm{O}$ (M.Wt. = $244.28 \mathrm{~g} / \mathrm{mol}$, 99\% purity) supplied by QReCTM.

\section{Scaling Test Rig}

Experiments were carried out using a test rig, which is schematically shown in Fig. (1). The core test equipment consists of five parts: constant pressure pump, transfer cell, oven, pressure transducer and core holder. There follows a brief description of each part.

Constant pressure pump: Double-piston plunger pump manufactured by Lushyong Machiney Industry Limited, with 1.5 horse power motor, maximum design pressure of 35 bars and approximate flow rate of $20 \mathrm{~L} / \mathrm{min}$ was used to inject the brines during flooding at different pressures.

Transfer cell: Stainless steel transfer cell manufactured by TEMCO, Inc., USA which can withstand pressures up to 10,000 psia was used to store and pump the injected brine to the core holder. The cell with a capacity of $1000 \mathrm{ml}$ has a free-floating piston, which separates the pump fluid (distilled water) from the injection brine. The pump fluid was pumped into a transfer cell to displace the brine into the core.

Oven: During all flooding runs, the core holder is placed inside a temperature controlled oven.

Pressure transducer: The differential pressure across the core during flooding runs was measured by using a pressure transducer (model E-913 033-B29) manufactured by Lushyong Machiney Industry Limited, with a digital display.

Core holder: A Hassler type, stainless steel core holder designed for consolidated core samples, 3 inch length and 1 inch diameter, was used. The holder was manufactured by
TEMCO, Inc., USA and could withstand pressures up to 10,000 psia. A rubber sleeved core holder, subjected to an external confining pressure, into which a sandstone core is placed.

\section{TEST PROCEDURES}

\section{Beaker Test}

The intent of this study was to determine solubility of barium sulphate scale from mixing synthetic brines (formation water and sea waters) at various temperatures 40 to 90 ${ }^{\circ} \mathrm{C}$. For each experiment of barium sulphate scale, $100 \mathrm{~mL}$ of each filtered opposite waters were poured simultaneously into a beaker. The synthetic brines were heated on hot plate and the solution was stirred by magnetic stirrer and after that the solution was filtered through $0.45-\mu \mathrm{m}$ filter paper. After filtration, $5 \mathrm{ml}$ of the filtrate was taken into a $50 \mathrm{ml}$ volumetric flask and was diluted with distilled water to make up to $50 \mathrm{ml}$ of solution. This instantaneous dilution of $\mathrm{BaSO}_{4}$ containing brines was performed in order to prevent $\mathrm{BaSO}_{4}$ precipitation between filtering and analytical determination of the barium concentration. The barium determination was calibrated by measuring $\mathrm{BaCl}_{2}$ standard solution. A barium concentration in the diluted filtrates was determined by atomic absorption spectrometry. After multiplying with the dilution factor, the exact concentration of barium was computed.

\section{Core Test}

Core Saturation: A schematic diagram of core saturation used in this study was shown in Fig. (2). Before each run, the core sample was dried in a Memmert Universal Oven at $100^{\circ} \mathrm{C}$ for overnight. The core sample was prepared for installation in the core-holder. A vacuum was drawn on the core sample for several hours to remove all air from the core. The core was saturated with formation water at room temperature. After the appearance of formation water at the outlet flooding was continued long enough to ensure $100 \%$ saturation.

Flooding Experiment: As shown in Fig. (1), the system consisting of the core holder assembly placed inside the oven and transfer cell containing sea water was then placed inside the water bath and heated to the desired temperature of the run. The required confining pressure was then adjusted to be approximately at double inlet pressure. A flooding run was

Table 2. Ions of Synthetic Formation and Injection Waters

\begin{tabular}{|c|c|c|c|c|}
\hline Ionic & $\begin{array}{c}\text { Normal Barium Formation Water } \\
\qquad(\mathbf{p p m})\end{array}$ & $\begin{array}{c}\text { High barium Formation Water } \\
(\text { (ppm) }\end{array}$ & $\begin{array}{c}\text { Barton Seawater } \\
\quad(\text { ppm) }\end{array}$ & $\begin{array}{c}\text { Angsi Seawater } \\
(\text { ppm })\end{array}$ \\
\hline Sodium & 42,707 & 42,707 & 9,749 & 10,804 \\
\hline Potassium & 1,972 & 1,972 & 340 & 375 \\
\hline Magnesium & 102 & 102 & 1,060 & 1,295 \\
\hline Calcium & 780 & 780 & 384 & 429 \\
\hline Barium & 250 & 2,200 & $<0.2$ & - \\
\hline Chloride & 66,706 & 67,713 & 17,218 & 19,307 \\
\hline Sulphate & 5 & 5 & 2,960 & 2,750 \\
\hline Bicarbonate & 2,140 & 2,140 & 136 & 159 \\
\hline
\end{tabular}




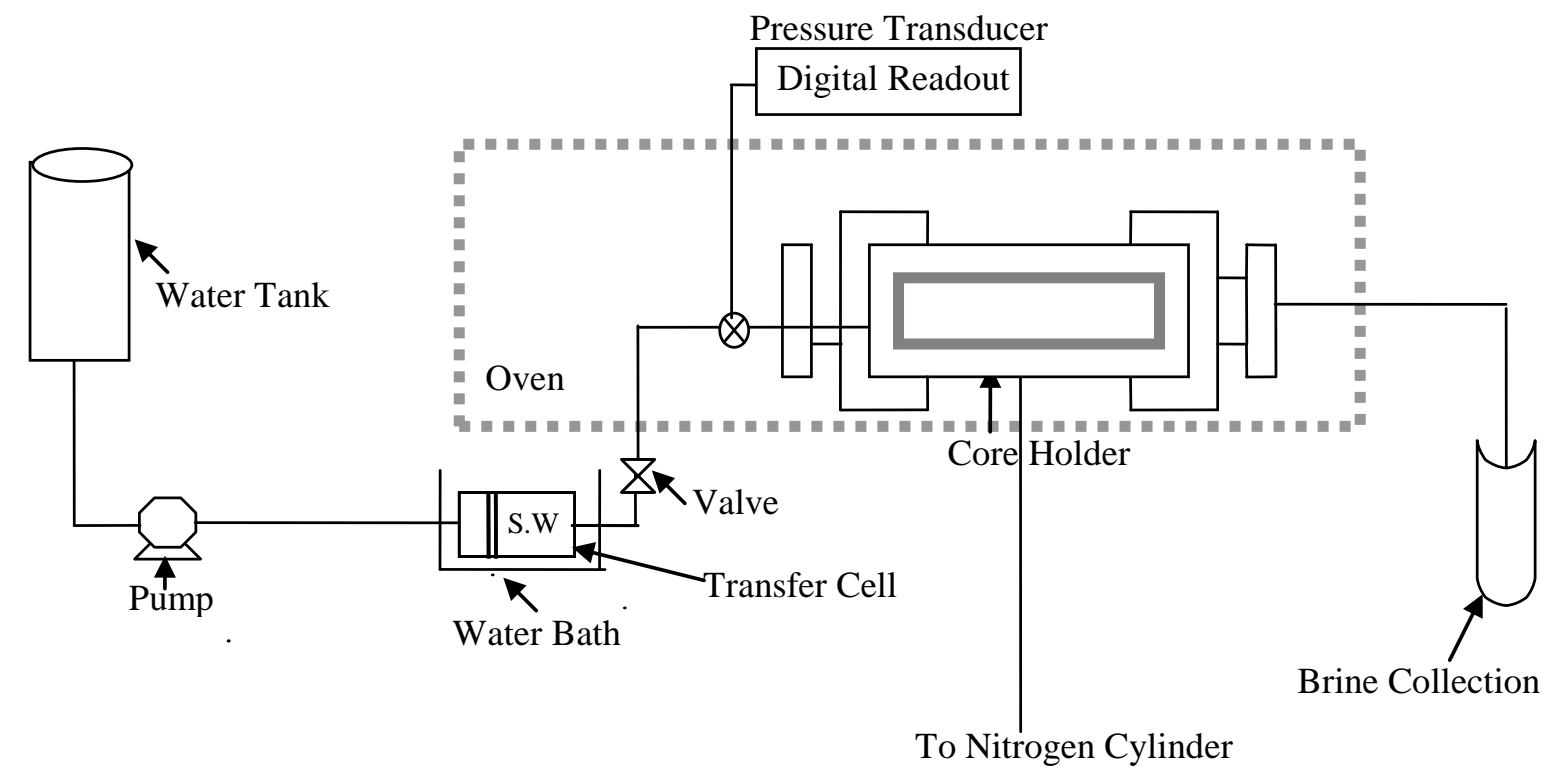

Fig. (1). Schematic of the core flooding apparatus.

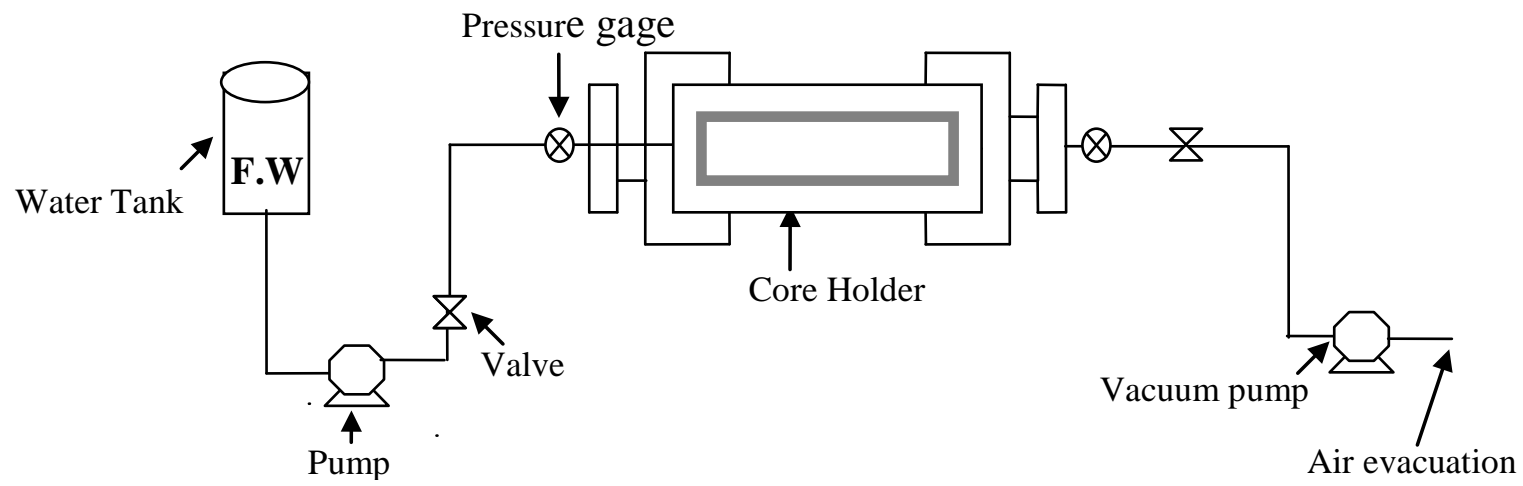

Fig. (2). Schematic of the core saturation apparatus.

started by setting plunger pump at different pressures. Thus, the sea water was injected into the core and mixed with formation water inside porous media. The inlet pressure was measured by pressure transducer while the outlet pressure was atmospheric pressure. During each run, the flow rate across the core was recorded continuously and the permeability of core was calculated with Darcy's linear flow equation before and after scale deposition. scale deposition have been observed, the core sample was removed at the end of flooding then dried and cut into sections for scanning electron microscopy (SEM).

\section{RESULTS AND DISCUSSION}

\section{Beaker Test}

The barium concentration in the diluted filtrates was determined by atomic absorption spectrometry. The solubility of $\mathrm{BaSO}_{4}$ at various temperatures of this study was calculated. Graphical presentations are given in Fig. (3).

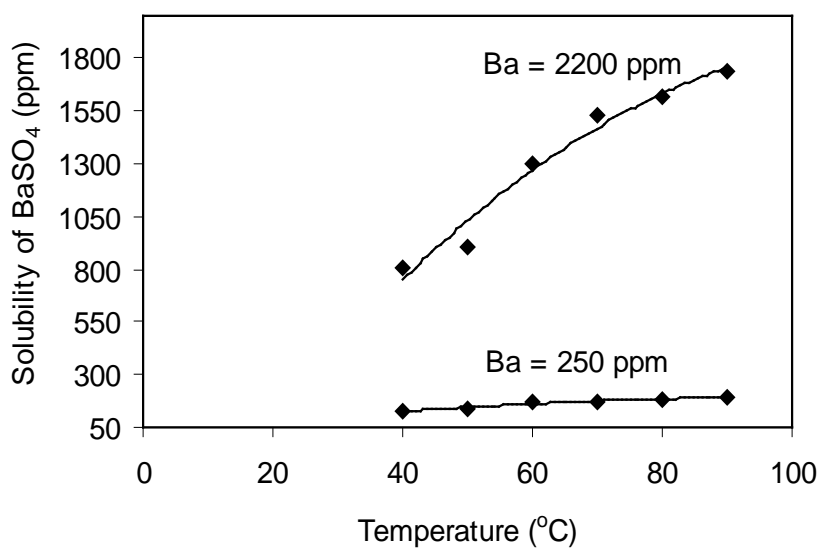

Fig. (3). $\mathrm{BaSO}_{4}$ solubility is dependent on temperature.

The expected trend in this temperature range is an increase in $\mathrm{BaSO}_{4}$ solubility because the dissociation of $\mathrm{BaSO}_{4}$ 
is endothermic reaction. A graphical presentation of the experimental results (Fig. 3) illustrates this trend in these experiments. The sulphate ion content in the sea water brine was reacted with barium ion during heating. The more precipitation of $\mathrm{BaSO}_{4}$ results from the presence of a large concentration of barium ion as compare to less precipitation at normal concentrations of barium ion.

\section{Core Test}

The main objective of this part of the investigation is to build a general reaction rate equation to predict $\mathrm{BaSO}_{4}$ deposition in sandstone cores and study permeability reduction caused by $\mathrm{BaSO}_{4}$ scale deposition in porous media.

During each run, the flow rate across the core was recorded continuously and the permeability of core was calculated using Darcy's linear- flow equation. The flow rate decreased during the experiments only when a super-saturated solution was flowing through the cores. This confirms that the decrease of flow rate is due to precipitation of the barium sulphate inside the core with the consequent reduction in its permeability and porosity. In the following, extend of permeability damage and the results for various temperatures, differential pressure, and super-saturation are discussed:

Extend of Permeability Reduction: Extend of permeability reduction caused by $\mathrm{BaSO}_{4}$ scaling in the rock pores varied in different situations. Fig. (4a) shows the permeability change of a less damaged core at temperature $\left(80^{\circ} \mathrm{C}\right)$ and differential pressure (100 psig); Fig. (4b) shows that of a severely damaged core after $\mathrm{BaSO}_{4}$ scaling at temperature $\left(50^{\circ} \mathrm{C}\right)$ and differential pressure (200 psig). About 5\% - 13\% permeability reduction is observed in Fig. (4a), but more than $9 \%-19 \%$ initial permeability reduction could occur in a heavily scaled core, as Fig. (4b) indicates. The reduction in permeability is possibly caused by crystals blocking the pore throats as shown in the SEM view of Fig. (11). The amount of precipitation varied within the sandstone cores, there being more scale near the formation water inlets and least scale was observed furthest from the inlet parts.

Effect of Temperature: Temperature has a significant influence on solubility and crystal growth of barium sulphate. To study its effect on the reaction rate constant and permeability reduction, a number of runs were carried out where concentration of injected brine and differential pressure were kept constant and temperatures were varied from 50 to $80^{\circ} \mathrm{C}$. Fig. (5) shows variation of permeability reduction with time at different temperatures. As temperature rises, the rate of nucleation and crystal growth and plugging are decreased. The permeability decline is less rapid at higher temperature, since the rate of $\mathrm{BaSO}_{4}$ precipitation decrease with temperature. This is because the solubility of $\mathrm{BaSO}_{4}$ increases with temperature. Fig. (6) shows variation of reaction rate constant with differential pressure at different temperatures. It also shows the effect of temperature on reaction rate constant. The reaction rate constant increases as the temperature is decreased.

Effect of Differential Pressure: To investigate the effect of differential pressure on the reaction rate constant and permeability reduction a number of runs were carried out. In these experiments, the concentration of brine and temperature were kept constant and differential pressure varied from 100

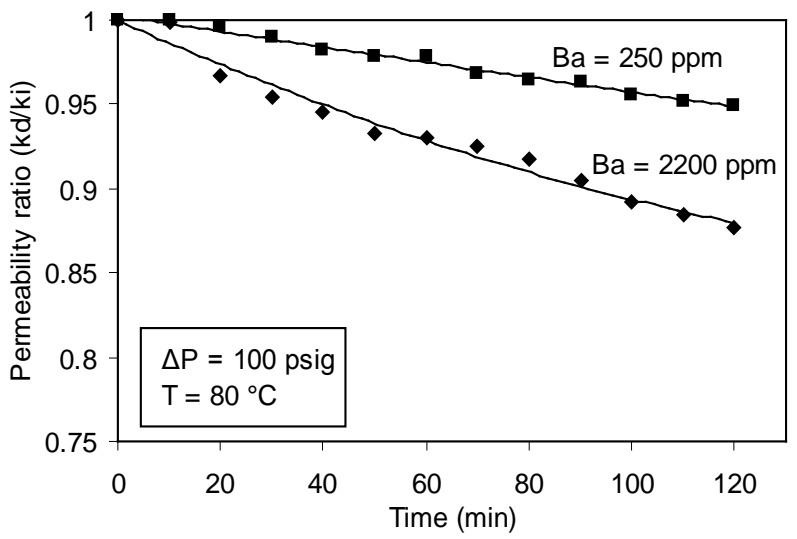

(a)

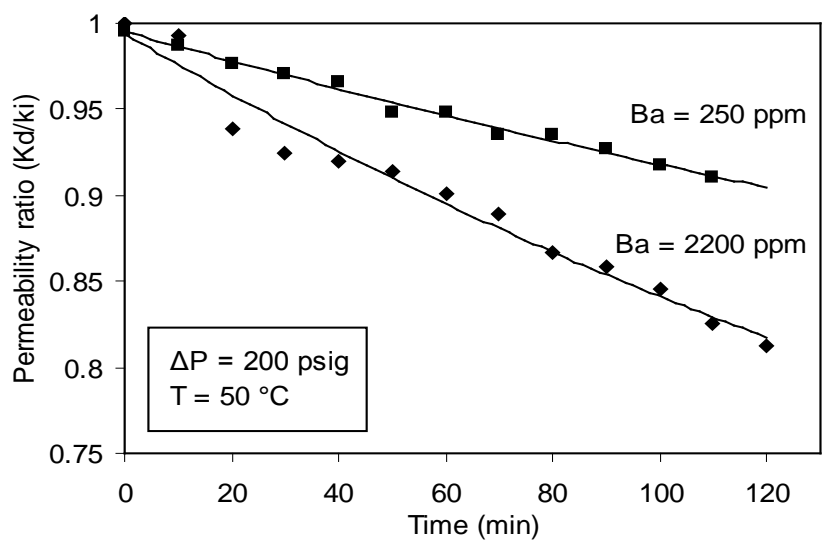

(b)

Fig. (4). Variation of permeability ratio as a function of time showing the effect of concentration at (a) 100 psig and $80^{\circ} \mathrm{C}$ (b) 200 psig and $50^{\circ} \mathrm{C}$.

to 200 psig. The variation of permeability reduction with time at different differential pressures is show in Fig. (7). From this figure, the permeability decline of porous medium is evident, even at such low differential pressures. The results illustrate that at low differential pressure, scale formation has already as significant effect on the permeability decline. As, the differential pressure was increased, the rate of permeability decline becomes more rapid. Moreover, at higher differential pressure more sulphate ions will pass through the porous medium in a given interval of time. Fig. (8) shows a variation of reaction rate constant with temperature at different differential pressures. This figure shows the effect of differential pressure on reaction rate constant. The reaction rate constant increases with increasing differential pressure.

Effect of Super-Saturation: A number of runs were carried out to study the effect of barium and sulphate concentrations on the precipitation reaction. These runs were performed at differential pressure from 100 to 200 psig and temperatures of $50-80^{\circ} \mathrm{C}$ with two different brine concentrations (see Table 2). Fig. (9) shows the increase in temperature causes a decrease in super-saturation, because the solubility of $\mathrm{BaSO}_{4}$ increases with temperature. This must have 


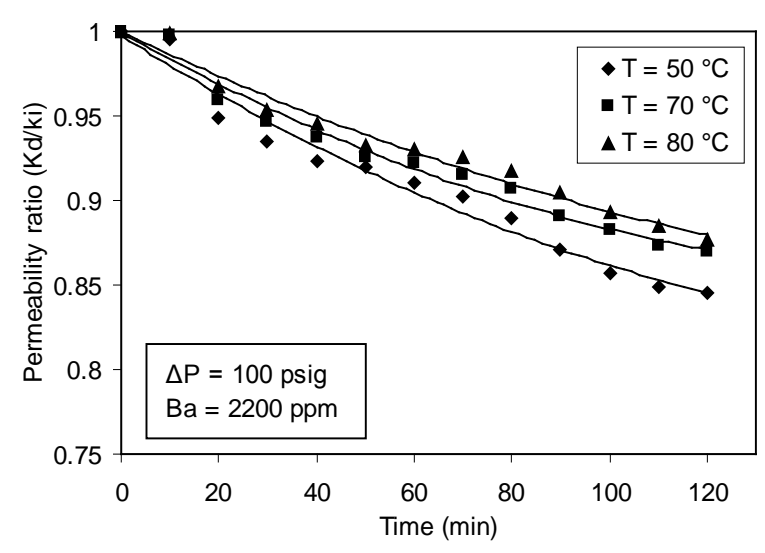

(a)

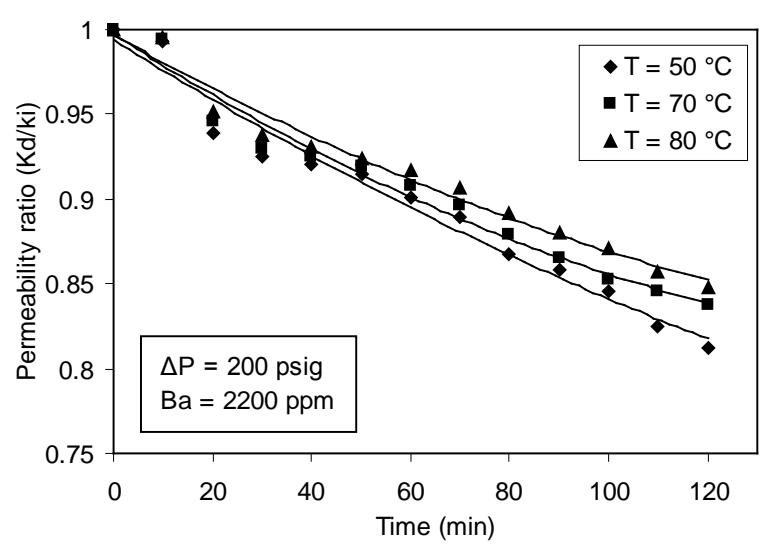

(b)

Fig. (5). Variation of permeability ratio as a function of time showing the effect of temperature at (a) 100 psig and (b) 200 psig.

led to the permeability decline is less rapid at higher temperature, since the rate of $\mathrm{BaSO}_{4}$ precipitation decrease with temperature.

Scanning Electron Microscopy Analysis: The scaled core samples were examined by scanning electron microscopy (SEM) to observe the particle size and morphology of the precipitates. The formation of $\mathrm{BaSO}_{4}$ during the flow of injection and formation waters in the porous media was observed by SEM micrographs. Fig. (11) shows the SEM image of the $\mathrm{BaSO}_{4}$ scaling crystals in rock pores precipitated from mixed seawater with formation water inside the cores. The average size of $\mathrm{BaSO}_{4}$ crystals precipitated from mixed brines was about $2.5 \mu \mathrm{m}$.

In all core tests, the abundance of scale reduced significantly from the front of the core to the rear indicating that scale formation in the porous media was rapid with the observation that the flow rate decreased soon after two incompatible waters were mixed into a core.

In general, Fig. (11) indicates that the front sections of a core suffered considerable greater scaling damage. The reason the scaling decreased downstream of a core is clear, most of the scaling ions had deposited within the front sections as soon as they were mixed and left few ions to precipitate from the flow stream in the rear sections. Fig. (10) shows a SEM image of an unscaled core samples.

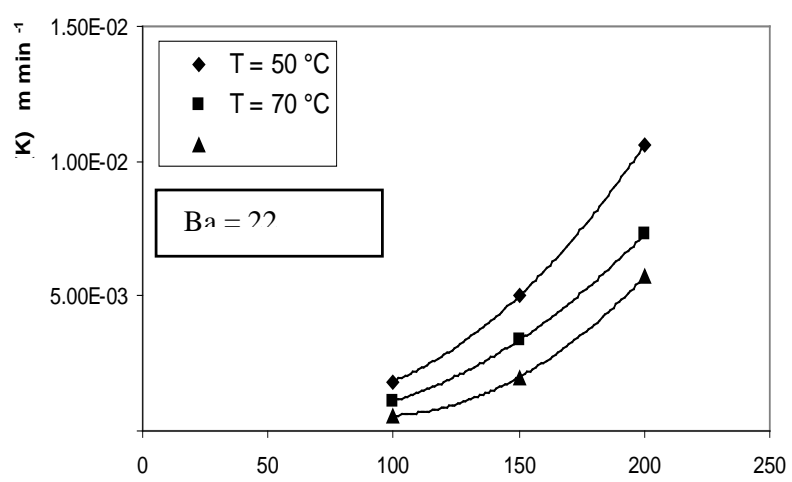

(a)

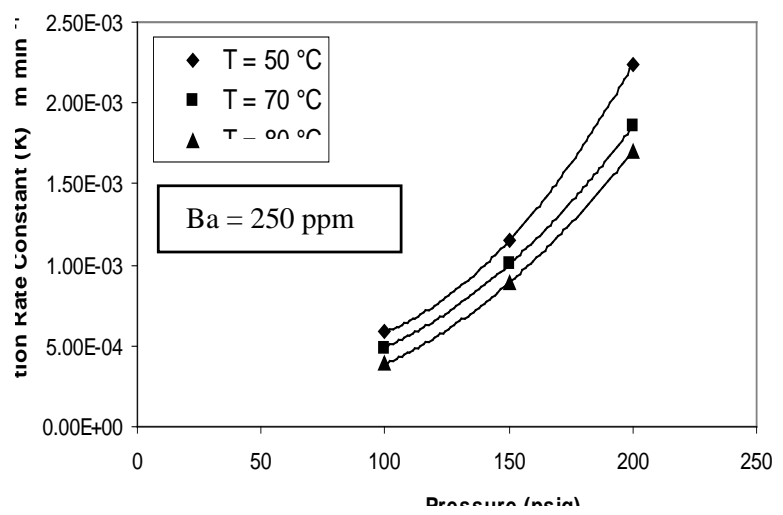

(b)

Fig. (6). Variation of reaction rate constant as a function of differential pressure showing the effect of temperature at a) $\mathrm{Ba}=2200$ ppm and b) $\mathrm{Ba}=250$ ppm.

\section{Rate Constant (K) Calculations}

Since barium concentration profile across the core is not available, the average reaction rate across the core is calculated by:

$$
\begin{aligned}
\text { Rate }(\mathrm{R}) & =\frac{-\mathrm{d} \mathrm{C}_{\mathrm{Ba}}}{\mathrm{dt}}=-\frac{\Delta C_{B a}}{\Delta t}=-\frac{C_{B a-o u t}-C_{B a-i n}}{\Delta t} \\
& =\frac{C_{B a-\text { in }}-C_{B a-\text { out }}}{\Delta t} \quad\left(\mathrm{~m} \mathrm{~min}^{-1}\right)
\end{aligned}
$$

$\Delta \mathrm{t}$ is the residence time of the brine in the core as given by:

$\Delta \mathrm{t}=\frac{\mathrm{V}_{\mathrm{p}}}{\mathrm{Q}}$

where,

Q: brine injection flow rate $\left(\mathrm{m} \mathrm{min}^{-1}\right)$

$\mathrm{V}_{\mathrm{p}}$ : pore volume of the core sample (ml)

A total of 7 runs were performed, giving, e.g., the following data of run 6 : 
$\Delta \mathrm{C}_{\mathrm{Ba}}=0.00035 \mathrm{~m}$ and $\Delta \mathrm{t}=0.18063 \mathrm{~min}$. Thus,

$R=\frac{0.00035}{0.18063}=0.00194 \mathrm{~m} \mathrm{~min}^{-1}$

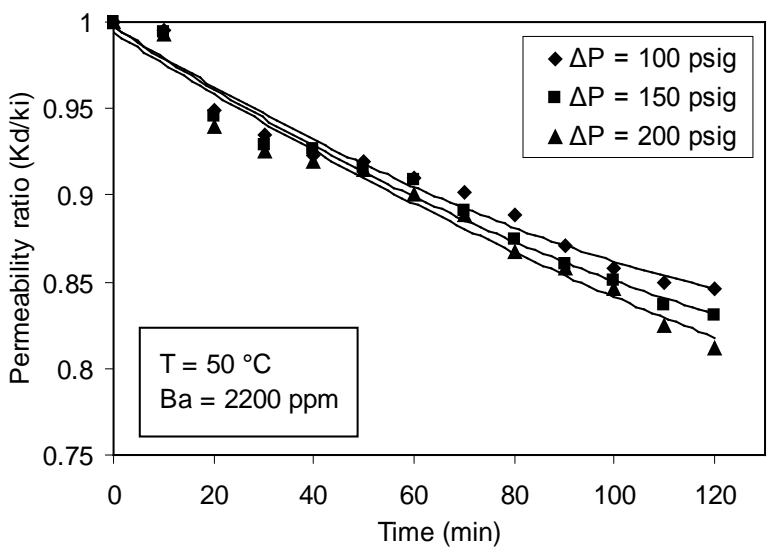

(a)

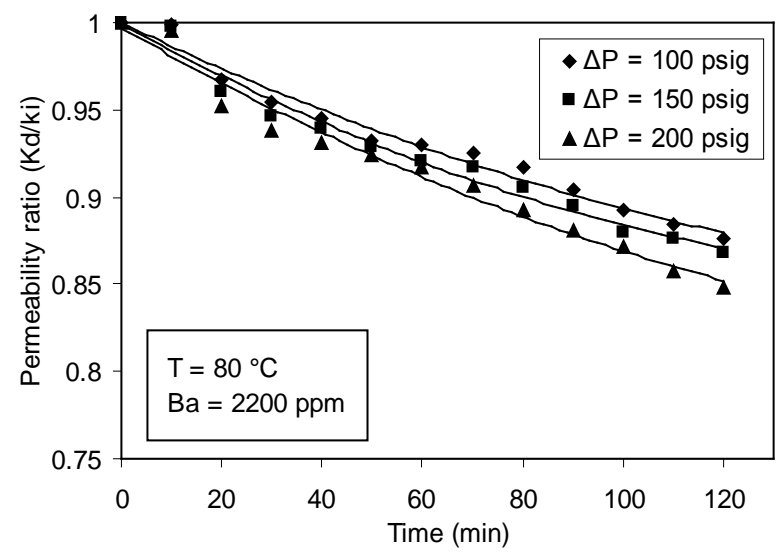

(b)

Fig. (7). Variation of permeability ratio as a function of time showing the effect of differential pressure at (a) $50^{\circ} \mathrm{C}$ and (b) $80^{\circ} \mathrm{C}$.

To compute the reaction rate constant for run 6 , a rate law is employed; however, with average values of $\mathrm{C}_{\mathrm{Ba}}, \mathrm{C}_{\mathrm{SO} 4}$, and $\mathrm{K}_{\mathrm{sp}}$ as demonstrated below using Equ. 6:

$K=R K_{s p} / \mathrm{C}_{\mathrm{Ba}} \mathrm{C}_{\mathrm{SO}_{4}}$

where,

$\mathrm{C}_{\mathrm{Ba}}, \mathrm{C}_{\mathrm{SO} 4:}$ average steady-state concentrations of the ions across the core $(\mathrm{m})$.

$\mathrm{K}_{\mathrm{sp}}$ : solubility product of $\mathrm{BaSO}_{4}$ in solution under the conditions of the reaction $(\mathrm{m})$.

Given the following data for run 6:

$\mathrm{C}_{\mathrm{Ba}}=(250+202.65) / 2=226.325 \mathrm{PPM}=0.00165 \mathrm{~m}$

$\mathrm{C}_{\mathrm{SO} 4}=(2855+2821.87) / 2=2838.435 \mathrm{PPM}=0.02960 \mathrm{~m}$ (outlet value estimated from material balance)

$\mathrm{K}_{\mathrm{sp}}=\left[\mathrm{Ca}^{2+}\right]\left[\mathrm{SO}_{4}{ }^{2-}\right]=0.00148 * 0.02943=0.00004 \mathrm{~m}^{2}$

The reaction rate constant becomes $\mathrm{K}=0.00159 \mathrm{~m} \mathrm{~min}^{-1}$ (a)

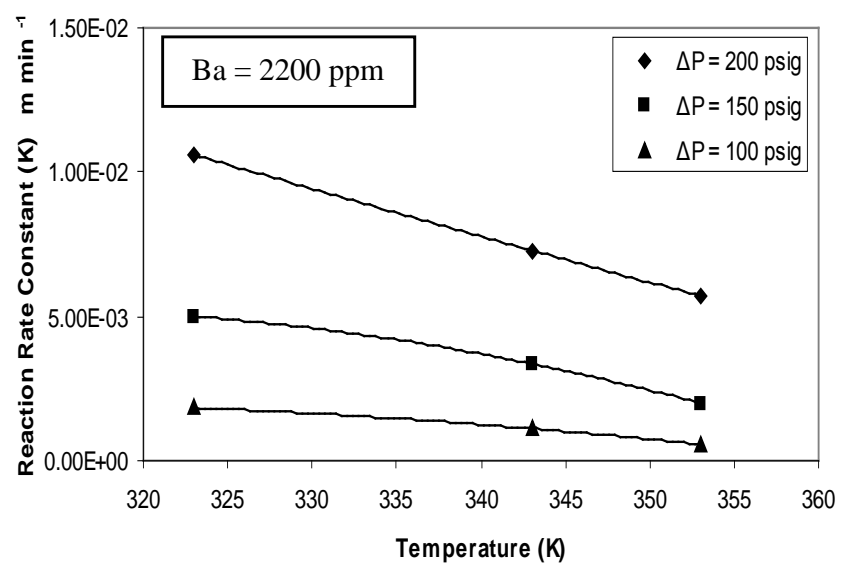

(b)

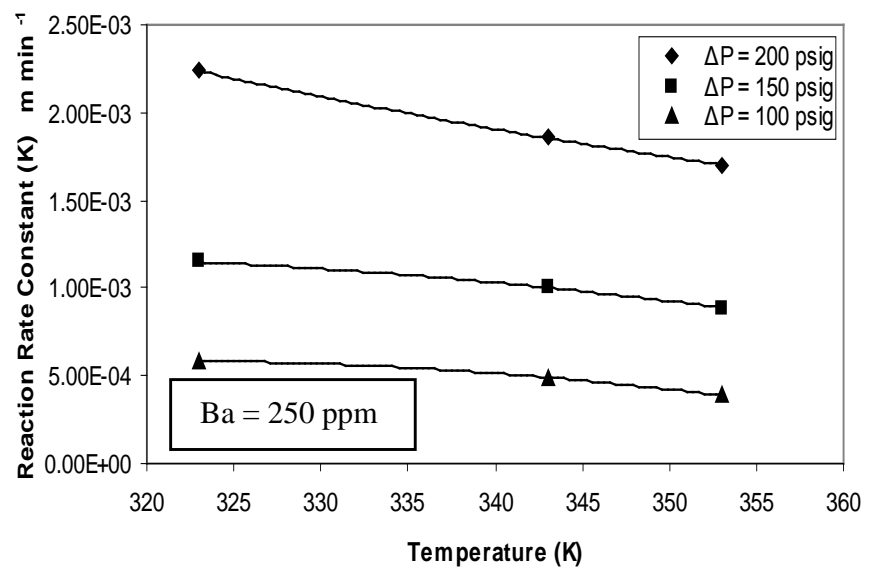

Fig. (8). Variation of reaction rate constant as a function of temperature showing the effect of differential pressure at (a) $\mathrm{Ba}=2200$ ppm and (b) $\mathrm{Ba}=250$ ppm.

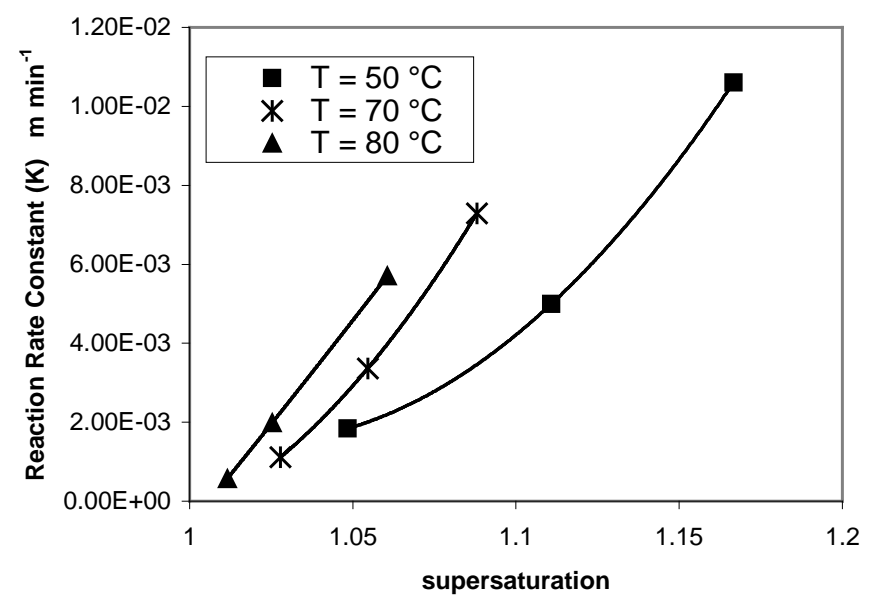

Fig. (9). Reaction rate constant $v s$ super-saturation.

\section{Kinetic Model}

The Arrhenius equation (Equ. 5) stipulates that $\mathrm{K}$ varies linearly with $1 / \mathrm{T}$ when all other reaction parameters are fixed. A plot of K (computed by Equ.6) versus 1/T for 7 runs reveals linear trends as shown in Fig. (12). The slope of lin- 
ear fits indicates the reaction's activation energy $\left(E_{A}\right)$ is $27.79 \mathrm{~kJ} / \mathrm{mol}$. Employing the Arrhenius equation with $\mathrm{E}_{\mathrm{A}}=$ -27.79 kJ/mol, values of A for those runs were computed and plotted in Fig. (13). The trend is described by:

(a)

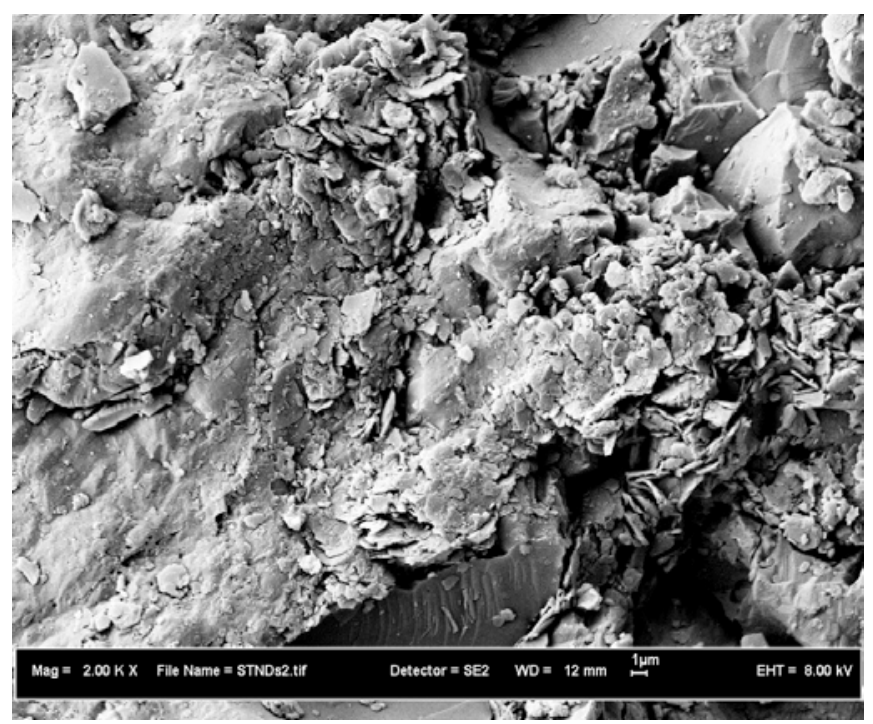

(b)

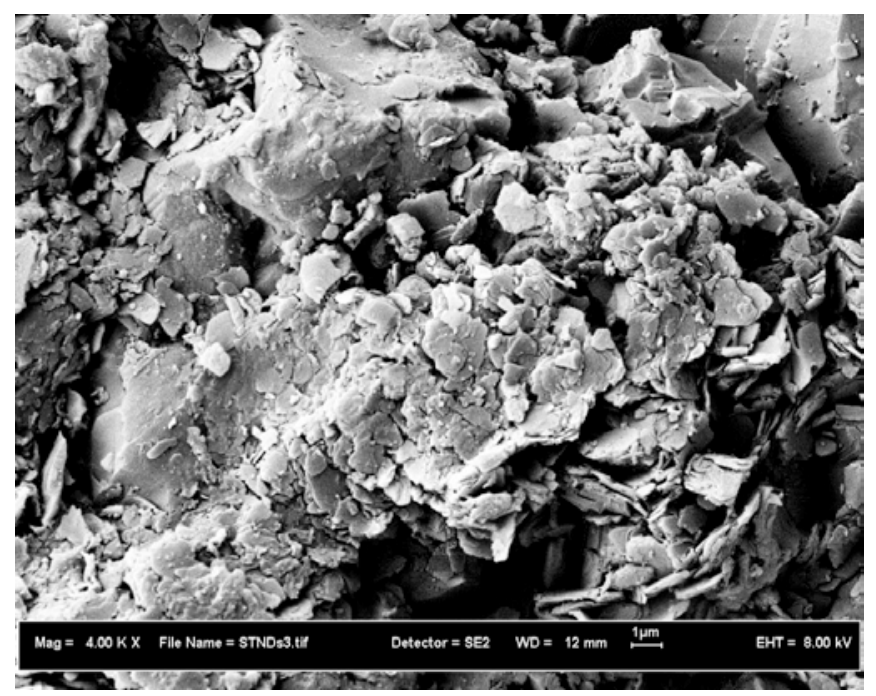

Fig. (10). SEM image of an unscaled sandstone core.

$A=2 * 10^{-11} * \Delta \mathrm{P}^{1.6567}$

Combining Equs.5 and 7, the general equation for the constant reaction rate should have the following form:

$K=2 * 10^{-11} * \Delta \mathrm{P}^{1.6567} * e^{\left(\frac{27790}{8.314 * T}\right)}$

The values of kinetic rate constant for 7 runs were obtained by substituting the operating parameters of each run $(\Delta \mathrm{P}$ and $\mathrm{T})$ into that equation. $\mathrm{A}$ plot of the $\mathrm{K}$ values predicted by Equ.8 versus the experimentally - determined values is shown in Fig. (14). The points show absolute percent errors averaging $10.23 \%$. (a)

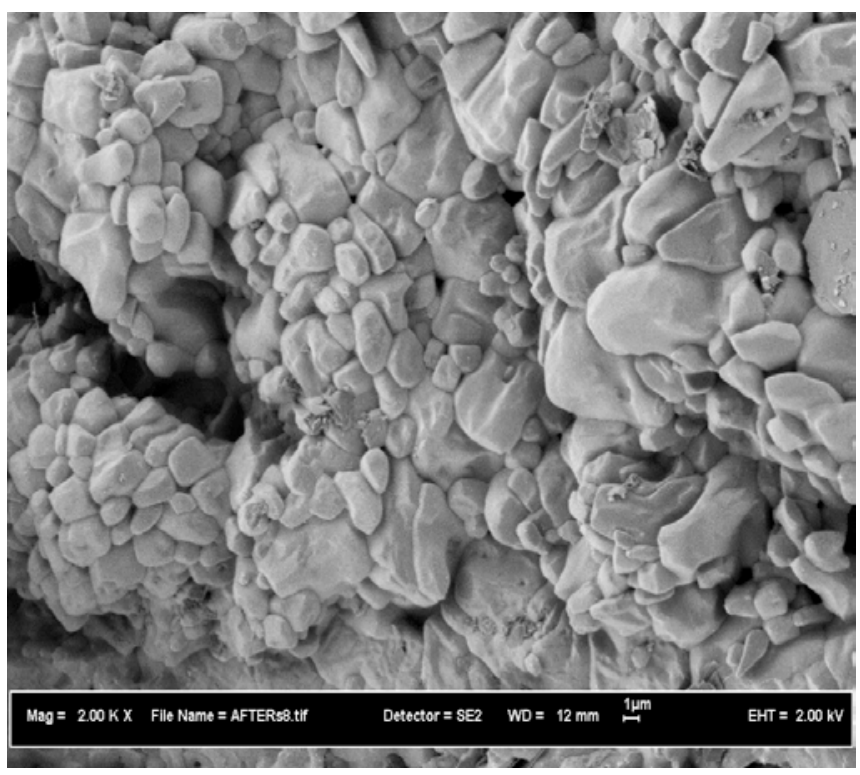

(b)

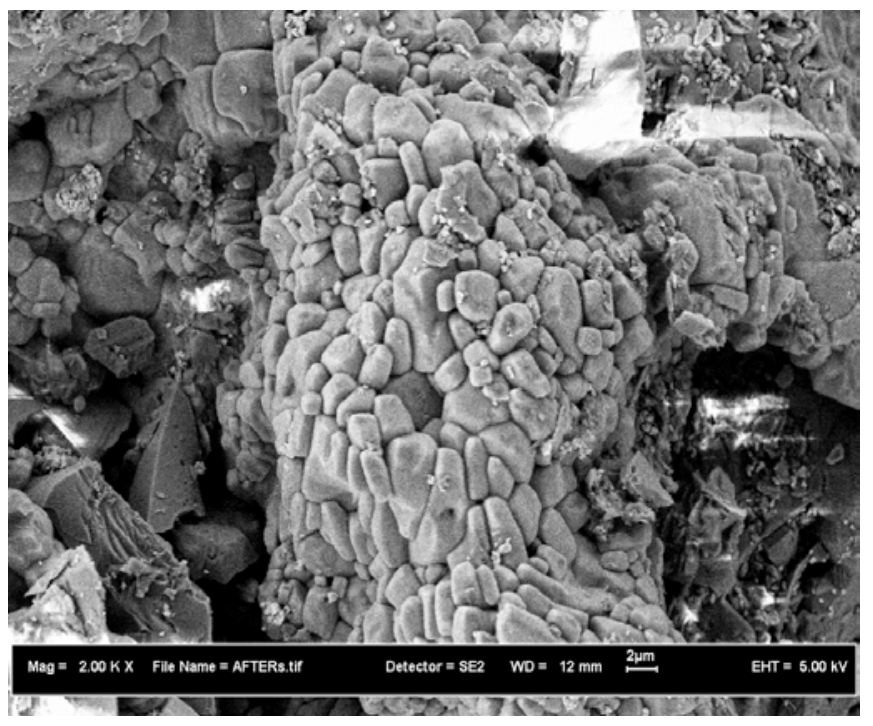

Fig. (11). SEM image of $\mathrm{BaSO}_{4}$ scales in sandstone cores.

\section{CONCLUSIONS}

- $\quad$ The experimental results confirm the general trend in solubility dependencies for common oil field scales, determined at various temperatures. A temperature rise from 40 to $90{ }^{\circ} \mathrm{C}$ causes an increase in $\mathrm{BaSO}_{4}$ solubility

- $\quad$ Permeability decline caused by $\mathrm{BaSO}_{4}$ scale formation in the porous media ranged from $5 \%$ to $19 \%$ of the initial permeability, depending on brine composition, initial permeability, temperature, differential pressure, and brine injection period.

- $\quad$ The pattern of permeability decline in a porous medium due to scaling injection was characterized by a concave curve with a steep initial decline which gradually slowed down to a lower. The initial 


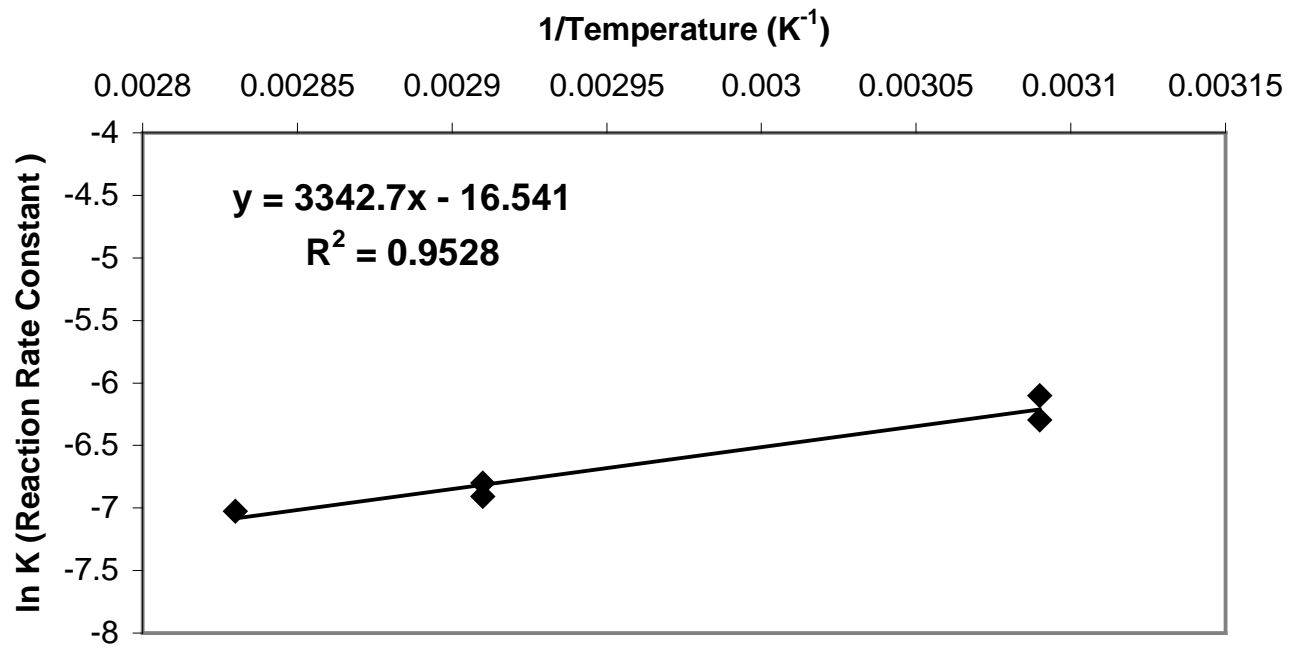

Fig. (12). Variation of rate constant with temperature.

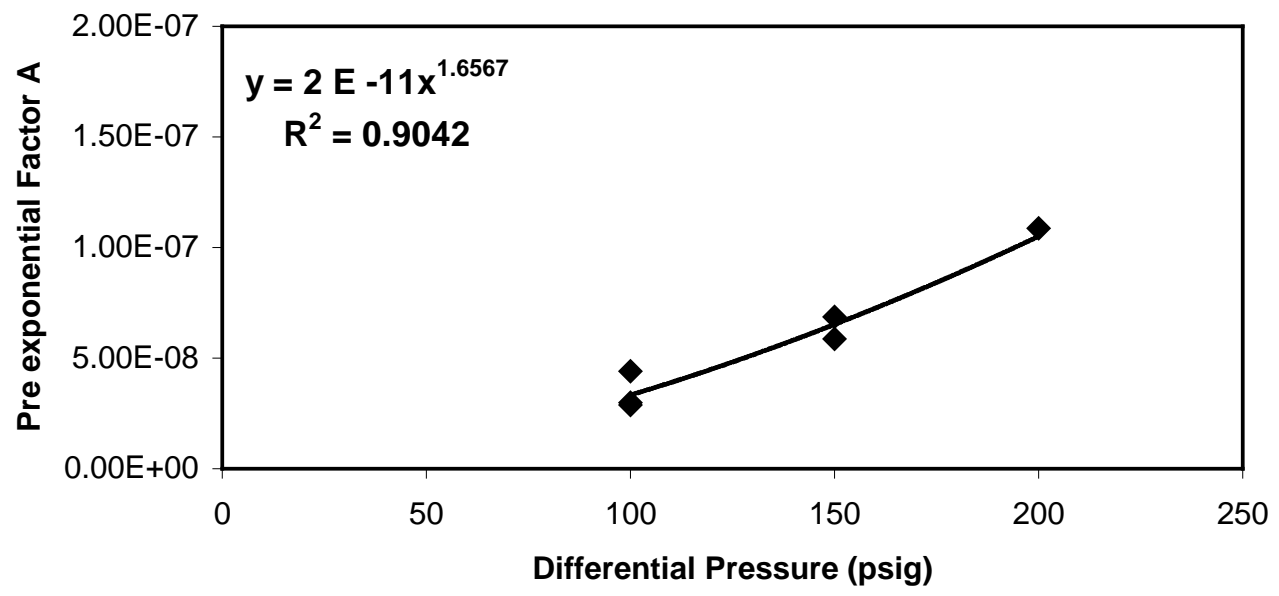

Fig. (13). Pre-exponential factor (A) with differential pressure.

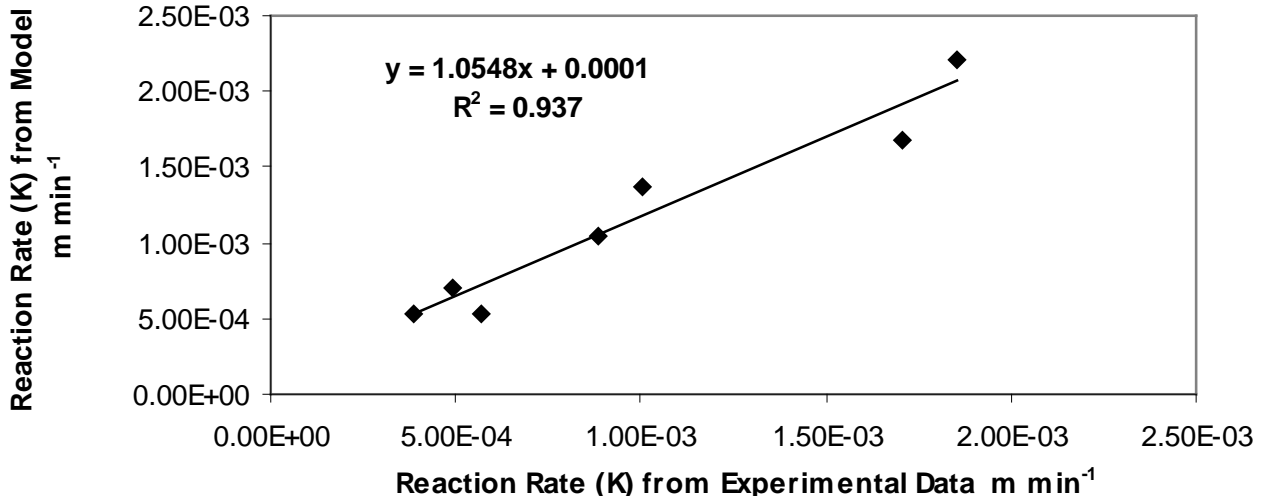

Fig. (14). Comparison between experimental and predicted kinetic rate constants for all 7 runs.

steepness of these curves generally decreased with increasing distance from the point of mixing of the incompatible brines. The concave shape of the permeability-time curves was common to the majority of the porous medium flow tests.

- $\quad$ Several factors influencing scale formation had been examined. Increasing temperature, super-saturation, and differential pressure had a detrimental effect on the permeability reduction and constant reaction rate.
- $\quad$ The formation of $\mathrm{BaSO}_{4}$ during flow of injection and formation waters in porous media have been proved by Scanning Electron Microscopy (SEM) micrographs show $\mathrm{BaSO}_{4}$ crystals formation in porous space

- $\quad$ The constant reaction rate $(\mathrm{K})$ varies with temperature according to Arrhenius equation. The reaction's activation energy was estimated at $-27.79 \mathrm{~kJ} / \mathrm{mol}$.

- The following kinetic rate constant equation for $\mathrm{BaSO}_{4}$ scale precipitation in sandstone cores fitted the experimental data rather well: 


$$
K=2 * 10^{-11} * \Delta \mathrm{P}^{1.6567} * e^{\left(\frac{27790}{8.314 * T}\right)}
$$

This equation yielded a mean absolute percent error of $10.23 \%$.

\section{ACKNOWLEDGEMENTS}

The authors would like to thank the University Technology Malaysia and Mosti for paid fees to publish this paper.

\section{REFERENCES}

[1] J. Moghadasi, M. Jamialahmadi, H. Muller-Steinhagen, A. Sharif, A. Ghalambor, R. M. Izadpanah, and E. Motaie, "Scale Formation in Iranian Oil Reservoir and Production Equipment during Water Injection", The 5th international oilfield scale symposium and exhibition, January 29-30, Aberdeen, UK, SPE 80406, 2003, pp.1-14.

[2] R. I. Collins and M. M. Jordan, "Occurrence, Prediction and Prevention of Zinc Sulfide Scale within Gulf Coast and North Sea High Temperature/High Salinity Production Wells”, The SPE third international symposium on oilfield scale, January 30-31, Aberdeen, UK, SPE 68317, 2001, pp.1-17.

[3] C. A. Todd and D. M. Yuan, "Barium and Strontium Sulfate SolidSolution Scale Formation at Elevated Temperatures”, SPE Production Engineering, SPE 19762, pp. 85-92, 1992.

[4] G.H. Bayona, "A Review of Well Injectivity Performance in Saudi Arabia's Ghawar Field Seawater Injection Program", The SPE middle east oil technical conference and exhibition, April 3-6, Bahrain, SPE 25531, 1993, pp. 201-214.

[5] K. Asghari and R. Kharrat, "Alteration of Permeability by Fine Particle Movement-A Water Injectivity Problem”, The SPE international symposium on oilfield chemistry, February 14-17, San Antonio, Texas, SPE 29006, 1995, pp. 655- 665.

[6] I. K. Andersen, E. Halvorsen, T. Saelensminde, and O. N. Ostbye, "Water Management in a Closed Loop - Problems and Solutions at Brage Field”, The SPE european petroleum conference, October 24-25, Paris, France, SPE 65162, 2000, pp. 1-12.

[7] J. Paulo, J. E. Mackay, N. Menzies, and N. Poynton, "Implications of Brine Mixing in the Reservoir for Scale Management in the Alba Field”, The 2001 SPE international symposium on oilfield scale, January 30-31, Aberdeen, UK, SPE 68310, 2001, pp.1-13.

[8] I. A. Voloshin, V. V. Ragulin, E. N. Tyabayeva, I. I. Diakonov, and J. E. Mackay, "Scaling Problems in Western Siberia", The SPE fifth international symposium on oilfield scale, January 29-30, Aberdeen, UK, SPE 80407, 2003, pp.1-8.

[9] M. Nassivera and A. Essel, "Fateh field sea water injection - Water Treatment, Corrosion, And scale control”, The middle east oil technical conference of the society of petroleum Engineers, March 25-29, Manama, Bahrain, SPE 7765, 1979, pp. 133-138.

[10] A. P. Read and K. J. Ringen, "The Use of Laboratory Tests to Evaluate Scaling Problems during Water Injection”, The SPE sixth international symposium on oilfield and geothermal chemistry, January 25-27, Dallas, Texas, SPE10593, 1983, pp. 7-17.

[11] J. O. Vetter, V. Kandarpa, and A. Harouaka, "Prediction of Scale Problems Due To Injection of Incompatible Waters", J. Pet. Technol., pp. 273-284, February 1982.

[12] J. Moghadasi, M. Jamialahmadi, H. Muller-Steinhagen, and A. Sharif, "Scale Formation in Oil Reservoir and Production Equipment during Water Injection (Kinetics of $\mathrm{CaSO}_{4}$ and $\mathrm{CaCO}_{3}$ Crystal Growth and Effect on Formation Damage)", The SPE European
Formation Damage Conference, May 13-14, Hague, Netherlands, SPE 82233, 2003, pp.1-12.

J. Moghadasi, H. Muller-Steinhagen, M. Jamialahmadi, and A. Sharif, "Model study on the kinetics of oil field formation damage due to salt precipitation from injection”, J. Petrol. Sci. Eng., vol.43, pp. 201-217, 2004.

[14] P. Bedrikovistsky, D. Marchesin, F. Shecaira, L. A. Serra, A. Marchesin, E. Reszende, and G. Hime, "Well Impairment During Sea/Produced Water Flooding: Treatment of Laboratory Data," The SPE Latin American and Caribbean petroleum engineering conference, March 25-28. Buenos Aires, Argentina, SPE 69546, 2001, pp.1-9.

[15] R. Stalker, R. I. Collins, and M. G. Graham, "The Impact of Chemical Incompabilities in Commingled Fluids on the Efficiency of a Produced Water Reinjection System: A North Sea Example”, The SPE international symposium on oilfield chemistry, February 5-7, Houston, Texas, SPE 80257, 2003, pp. 1-13.

[16] C. Khelil, A. Harouaka, and A. Delhoume, "Water Injection in Algeria-Problems and Solutions", The middle east oil technical conference of the Society of petroleum engineers, March 25-29, Manama, Bahrain: SPE 7762, 1979, pp. 97-106.

[17] J. E. Mackay, "Scale Inhibitor Application in Injection Wells to Protect Against Damage to Production Wells", The SPE european formation damage conference, May 25-27. Scheveningen, Netherlands, SPE 95022, 2005, pp.1-9.

[18] M. M. Jordan and J. E. Mackay, "Integrated Field Development for Effective Scale Control Throughout the Water Cycle in Deep Water Subsea Fields", The SPE Europe/EAGE annual conference, June 13-16, Madrid, Spain, SPE 94052, 2005, pp.1-9.

[19] D. Y. Yeboah, K. S. Somuah, and R. M. Saeed, "Anew and Reliable Model for Predicting Oilfield Scale Formation”, The SPE international symposium on oilfield chemistry, March 2-5. New Orieans, USA., SPE 25166, 1993, pp.1-10.

[20] W. R., Mitchell, M. D. Grist, and J. M. Boyle, "Chemical Treatments Associated With North Sea Projects”, J. Petrol. Technol., SPE 7880, pp. 904-912, 1980.

[21] C. J. Lindlof, and G. K. Stoffer, “A case study of sea water injection incompatibility”, J. Pet. Technol., pp. 1256-1262, July 1983.

[22] J. O. Vetter, A. W. Farone, E. Veith, and S. Lankford, "Calcium Carbonate Scale Considerations: A Practical Approach”, The SPE production technology symposium, November 16-17, Lubbock, Texas, SPE 17009, 1987, pp.1-14.

[23] J. P. Shuler, A. E. Freitas, and A. K. Bowker, "Selection and Application of $\mathrm{BaSO}_{4}$ Scale Inhibitors for a $\mathrm{CO}_{2}$ Flood, Rangely Weber Sand Unit, Colorado”, Soc. Petrol. Eng., SPE 18973, pp. 1-8, 1991.

[24] I. M. El-Hattab, “GUPCO'S Experience in Treating Gulf of Suez Seawater for Waterflooding the El Morgan Oil Field”, J. Petrol. Technol., pp.1449-1460, July 1982.

[25] H. G. Nancollas and T. S. Liu, "Crystal Growth and Dissolution of Barium Sulfate”, Soc. Petrol. Eng. J., pp. 509-516, December 1975.

[26] P. G. Bedrikovistsky, R. P. Lopes, F. F. Rosario, M. C. Bezerra, and E. A. Lima, "Oilfield scaling- part 1: mathematical and laboratory modelling”, The SPE Latin American and Caribbean petroleum engineering conference., April 27-30, Trinidad, West Indies, SPE 81127, 2003, pp. 1-13.

[27] P. G. Bedrikovistsky, R. P. Lopes, F. F. Rosario, M. C. Bezerra, and E. A. Lima, "Barium sulphate oilfield Scaling: Mathematical and laboratory Modelling”, The SPE $6^{\text {th }}$ international symposium on oilfield scale, May 26-27, Aberdeen, UK, SPE 87457, 2004, pp. $1-13$. 